\title{
L. Notes on the history of English geology
}

\section{William Henry Fitton M.D. F.R.S.}

To cite this article: William Henry Fitton M.D. F.R.S. (1832) L. Notes on the history of English geology, Philosophical Magazine Series 3, 1:4, 268-275, DOI: $10.1080 / 14786443208647890$

To link to this article: http://dx.doi.org/10.1080/14786443208647890

册 Published online: 01 Jun 2009.

Submit your article to this journal 준

III Article views: 3

Q View related articles $\sqsubset$ 


\section{$\left[\begin{array}{ll}268 & ]\end{array}\right.$}

\section{Notes on the History of English Geology. By William Henry Fitton, M.D. F.R.S. \&c.}

[Continued from p. 160.]

$\mathrm{B}^{\mathrm{UT}}$ the most important observations, perhaps, that have ever yet appeared on the subject of stratification, are those of the Rev. John Michell, in a paper ' On the Cause and Phenomena of Earthquakes,' published in the Philosophical Transactions for 1760*; where the author not only describes the general appearance and structure of stratified countries, but explains most clearly the arrangement of the strata in England:- and this, not as confined to Britain, but as exemplifying a general principle, which he supposes to hold universally in other parts of the globe.

' The earth,' he says, ' (as far as we can judge from the ' appearances,) is not composed of heaps of matter casually ' thrown together, but of regular and uniform strata. These ' strata, though they frequently do not exceed a few feet, or ' perhaps a few inches in thickness, yet often extend in length ' and breadth for many miles, and this without varying their ' thickness considerably. The same stratum also preserves a ' uniform character throughout, though the strata immediately ' next to each other are often totally different.'

The perpendicular fissures of the strata are then noticed, their bendings, and their position, which is stated to be, in a general view, horizontal.- ' What is very remarkable, however, ' in their situation is, that from most, if not all, large tracts of ' high and mountainous countries, the strata lie in a situation ' more inclined to the horizon than the country itself, the ' mountainous countries being generally, if not always, formed ' out of the lower strata of earth. This situation of the strata ' may be not unaptly represented in the following manner: ' Let a number of leaves of paper, of several different sorts ' of colours, be pasted upon one another; then bending them ' up together into a ridge in the middle, conceive them to be ' reduced again to a level surface by a plane, so passing - through them as to cut off all the part that had been raised; ' let the middle now be again raised a little, and this will be ' a good general representation of most, if not of all, large

* Vol. li. Part ii. Sections 37 to 49, p. 566, \&c.--Mr. Farey states that Mr. Michell was appointed Woodwardian Professor at Cambridge, about 1762; an office which he held, we believe, for about eight years. He was then, unfortunately for Geology, transferred to the Rectory of 'Thornhill, near Wakefield, in Yorkshire; and died on the 21st of April 1793. Mr. Michell was the author also of some excellent Astronomical papers in the Philosophical Transactions. 
' tracts of mountainous countries, together with the parts ad'jacent, throughout the whole world*.

- From this formation of the earth, it will follow, that we ' ought to meet roith the same kinds of earths, stones, and mi' nerals, appearing at the surface, in long narrow slips, and ' lying parallel to the greatest rise of any long ridges of monn- tains; and so, in fact, we find them. The Andes, in South - America, has a chain of volcanos that extend in length above ' 5000 miles: these volcanos, in all probability, are all de- rived from the same stratum. Parallel to the Andes is the - Sierra, another long ridge of mountains, that run between ' the Andes and the sea:' and 'these two ridges of moun' tains run within sight of one another, and almost equally : ' for above a thousand leagues together + being each at a me' dium above twenty leagues wide.

' The same thing is found to obtain in North America also. - The great lakes, which give rise to the river St. Lawrence, ' are kept up by a long ridge of mountains, that run nearly ' parallel to the eastern coast. In descending from these to- wards the sea, the same sets of strata, and in the same order, - are generally met with throughout the greatest part of their ' length \pm .

'In Great Britain we have another instance to the same pur' pose, where the direction of the ridge varies about a point from 'due north and south, lying nearly from $N$. by E. to S. by W. $\$$ - There are many more instances of this to be met with in the " world, if we may judge from circumstances, which make ' it highly probable that it obtains in a great number of places; ' and in several they seem to put it almost out of doubt.

- The reader is not to suppose, however, that, in any in' stances, the highest rise of the ridge, and the inclination ' of the strata from thence to the countries on each side, is perfectly uniform, for they have frequently very considerable 'inequalities, and these inequalities are sometimes so great ' hat the strata are bent, for some small distance, even the ' ontrary way from the general inclination of them. This ' OJen makes it difficult to trace the appearance I have been re.

- latng, wohich, without a general knoweledge of the fossil bodies ' of ilarge tract of' country, it is hardly possible to do.

- A considerable distances from large ridges of mountains, ' the sata, for the most part, assume a situation nearly level;

* Fis3. (Plate II.) represents a section of a set of strata, lying in the ' situationiust described. The section is supposed to be made at right

' angles to ye length of the ridge, and perpendicular to the horizon.'

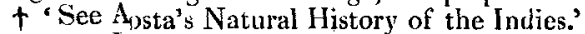

† 'See Ltis Evans's Map, and Account of North America.'

$\$$ "Of this,Mr. Micleell adds in a note, 'I could give many undoubted. proofs, if it weld not too far exceed the limits of my present design.' 
- and as the mountainous countries are generally formed out ' of the lower strata, so the more level countries are generally - formed out of the upper strata of the earth.

- Hence it comes to pass that, in countries of this kind, the ' same strata are found to extend themselves a great way, as 6 reell in breadth as in length. We have an instance of this in ' the chalky and flinty countries of England and France, which ' (excepting the interruption of the Channel, and the clays, ' sands, \&c. of a few counties,) compose a tract of about three ' hundred miles each way.'

The account of the districts in America, above referred to, has been confirmed, we believe, in general, by more recent observations : and nothing can be more clear than Mr. Michell's exposition of the principle of the stratification of England. That he was acquainted with the detail also, is proved by a memorandum discovered in 1810, among the papers of Mr. Smeaton, then in the hands of Sir Joseph Banks; in which are enumerated several of the principal beds, from the chalk down to the coal; detached portions, several miles distant from each other, being, in two instances, associated under the same name.-This paper is as follows*:

- Mr. Michell's Account of the South of England Strata.

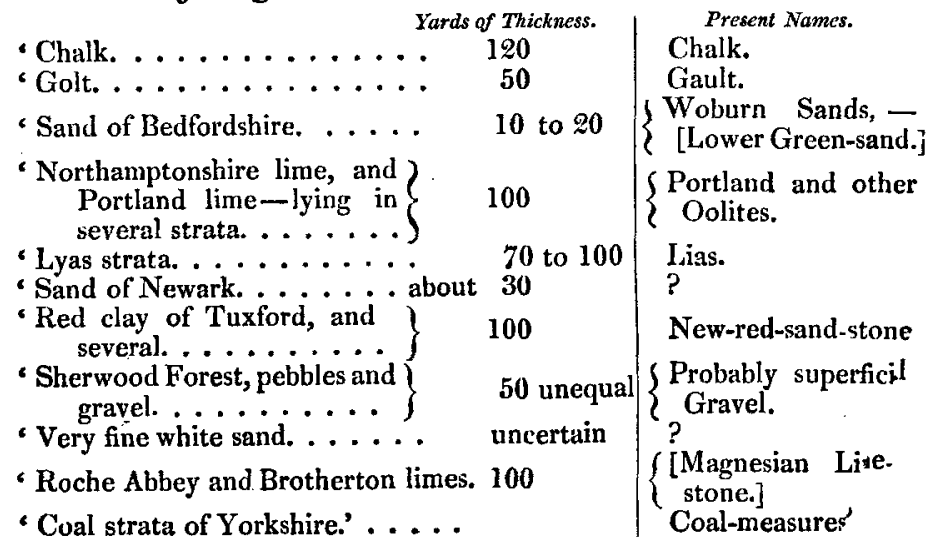

It is extraordinary that the very remarkable paperin the Philosophical Transactions from which the foregoing 3 xtracts

* We are indebted to the late Mr. Farey for the publica on of this valuable document, in the Philosophical Magazine, vol. xxxvi... 102, \&c.; and the list of modern names above given has been adopte from hin. The thickness of most of the strata, he justly observes, is great underrated. -The list was found, in Mr. Smeaton's writing, on a part $c$ the back of a letter bearing the London post-mark of November 21, 188. Smeaton himself died in September 1792. 
have been taken, embracing general principles of such importance, does not appear to have been mentioned, or alladed to by any writer on geology, either in this country or upon the Continent, during a subsequent period of more than fifty years. This may, perhaps, be accounted for, in some degree, by the title and immediate subject of the paper itself; but it must be ascribed principally to the very languid state of inquiry as to the structure of the earth, in England, for a long time after its appearance**

[A still more interesting question is, - Whether by the words "fossil bodies," without a general knowledge of which ' in a large tract of country,' Mr. Michell states, ' it is hardly ' possible to trace the appearances he has been relating'-he intended to signify the organized remains included in the strata:-For, if that were his meaning, there would really be very little in the doctrines of modern geology, in which, as to principle, he did not take the lead. This, however, does not appear to have been the case. Mr. Sedgwick has very justly stated + , that no part of the Woodwardian Collection, which was for some years under Mr. Michell's immediate superintendance is stratigraphically arranged; and that, not only in the works and catalogues of Woodward, but in the language of other English naturalists of the last century, every mineral substance was designated under the general term 'fossil;:' organic remains almost always distinguished by the name of 'extraneous fossils, organic fossils,' \&c. Nor is there any reason to suppose, that Mr. Michell's arrangement of the British strata was made public till the accidental discovery of the slight document above mentioned, many years after Mr. Smith's inquiries had begun; indeed, at a period when his Map of England was far advanced towards publication.]

The next author of note is W HITEH URST, whose Inquiry into the Original State and Formation of the Earth was first published in the year 1778, and reprinted, with considerable improvements, in 1786. A great part of this book is infected with that taste for cosmogony which had misled so many of the author's predecessors; but if the reader be not repelled by the formidable chapters ' Of the component parts of chaos whither homogeneous or heterogeneous,' and 'Of' the period of human life before and after the Flood,' he will find some excellent remarks upon organized fossils; and in the latter part

- After the first publication of Dr. Fitton's article in the Edinburgh Review, Mr. Michell's paper on Earthquakes was reprinted in full, in Phil. Mag. vol. lii. beginning at p. 186.-EDIT.

$\uparrow$ Address to the Geological Society, at the Anniversary, February 1831. Proceedings, p. 274 (or Phil. Mag. and Annals, N.S. vol. ix. p. 275.-EDrT.) 


\section{Dr. Fitton's Notes on the History of English Geology.}

of the volume, especially the chapter ' on the Structure of Derbyshire and other parts of England,' abundant proofs of the author's acuteness and fidelity as an observer. His statements, indeed, concur precisely with those of Mr. Michell; ' the arrangement of the strata being such,' he tells us, 'that ' they invariably follow each other, as it were, in alphabetical - order, or as a series of numbers. I do not mean to insinuate - that the strata are alike in all the different regions of the - earth, with respect to thickness or quality-for experience shows - the contrary; but that in each particular part, how much so- ever they may differ, yet they follow each other in a regular ' succession*.'-' It was my intention,' he says in another place, ' to have deposited specimens of each stratum, with its pro' ductions, in the British Museum, arranged in the same order ' above each other as they are in the earth; being persuaded - that such a plan would convey a more perfect idea of sub' terraneous geography, and of the various bodies inclosed in ' the earth, than words or lines can possibly express †.' But it is remarkable that Whitehurst, at the close of his work, appears to dwell with much more pleasure on that part which relates to the early ages of the world, and the condition of its antediluvian inhabitants, ' who slept away their time in sweet ' repose upon the ever verdant turf,' than upon the truly important and substantial part of his performance.

The most direct instance that we have met with, of the actual tracing the course of any of the strata in England, before the commencement of Mr. Smith's investigations, occurs in the celebrated work of SMEaton on the Eddystone Lighthouse $;$; and it affords an excellent proof of the practical benefit to be derived from geological inquiries. Mr. Smeaton was in want of lime which possessed the property of forming a good cement for works exposed to the sea; and finding the lime afforded by the lias limestone at Aberthaw, on the coast of Glamorganshire, to answer his purpose $\oint$, he was led to seek for stone of the same qualities in other places. This he found, in the first instance at Watchet, on the Somersetshire coast, ' where ' all agreed, that they were the very same stratum of lias lime-

* Whitehurst, Second Edition, pp. 178, 179.

$\uparrow$ Pages 204, 205.-This project has since been executed; Government having, in 1806, purchased, for the British Museum, Mr. Smith's collection of fossils, arranged according to the crder of the strata :-an acquisition certainly of the highest interest in the scientific annals of our country, and deserving a most distinguished place in a great national repository.

$\ddagger$ London, folio, 1791. Sections 168-190, \&c. In the Introduction it is stated that the book was printed in $\mathbf{1 7 8 6}$.

$\delta$ The best cement was found to be a compound of equal parts of bluelias lime and puzzolano. 
Dr. Fitton's Notes on the History of English Geology. 273

' stone, that were found on each side the Channel, though at ' the distance of twenty miles.' $\mathrm{He}$ went accordingly, to Watchet, and examined the situation of the beds there, which he has very well described; and he subsequently traced the progress of the lias, through Monmouthshire and the intermediate counties, as far north as Newark in Nottinghamshire; a course which corresponds precisely with the results of more recent investigation. He mentions likew ise, that $\mathrm{Mr}$. Cavendish and Dr. Blagden had assured him of its existence at Lyme, on the coast of Dorsetshire; which is the more remarkable, as a considerable mass of other strata intervenes, upon the surface, between that place and those which Mr. Smeaton had examined himself. It is not however improbable, that Smeaton's inquiries upon this subject may have been connected with some previous communication with Mr. Michell; since he appears to have received from that gentleman, the list of the strata to which we have already referred, before the publication of his own work on the Lighthouse.

It is difficult to trace the history of WERNER's doctrines; the most important of his tenets having been delivered only in the form of lectures; while the writings of his pupils, who confessedly borrowed from their master, are generally diluted with large additions of their own. In England especially, a correct view of Werner's geological system was not obtained till long after its promulgation: it was not indeed accessible to persons unacquainted with the German language, till the publication of Mr. Jameson's volume of Geognosy, in 1808 ; and was very imperfectly appreciated for a considerable time afterwards; the controversy between the Wernerian and Huttonian schools, having called off the attention of those engaged in the study of Geology, to the speculative department of their subject, from the more solid occupation of inquiry into the actual structure of the globe. The Kürze Klassifikation of Werner, a brief but valuable arrangement and description of rocks, published by himself in $1787^{*}$, has no allusion nor hint at the doctrine of Formations, the term not once occurring in that work. Nor was the distinction of the transi tion from the floetz class introduced into his arrangement for some years afterwards; grey-wacké being placed, in the list of 1787, among the flotz sand-stones. The opinions of Werner, as to the origin of the basaltic rocks, were formed after his examination of the Scheibenberg in $1787+$. The

* Kürze Klassifikation und Beschreibung den verschiedenen Gebirgsarten.

Von A. G. Werner, \&c. Dresden, 1787. 4to, pp. 28.

+ Bergmännisches Journal, 1788, vol. ii. p.845.

Third Series. Vol. 1. No. 4. Oct. 1832. 


\section{Dr. Fitton's Notes on the History of English Geology.}

doctrine of formations was delivered in his lectures only, and may be dated as of 1790 or 1791 ; that of the transition-class not until 1795 or 1796 . But his theoretic views, as to the deposition of rocks in general, and the configuration of the earth's surface, - which, after all, (if what relates to the overlying formations be excepted, are little more than a selection from the doctrines of preceding writers, may be collected from his work on Veins, first published in November 1791; at which time it is certain that he was acquainted with the works of Whitehurst, for they are quoted in the book last mentioned.

The true merit of Werner, on which it is probable his reputation as a naturalist will ultimately rest, appears, to consist, in his having drawn the attention of geologists, explicitly, to the Order of succession which the various natural groups of rocks are found in general to present; and in having himself developed that order, to a certain extent, with a degree of accuracy which before was scarcely attainable, from the want of sufficient methods of discriminating minerals and their compounds. He was, we believe, the first to observe, or the first to diffuse the doctrine, that the masses or strata, constituting the surface of the globe, present themselves in groups or assemblages, the members of which are generally associated wherever they occur, and are so connected as to exhibit a certain unity of character. To such assemblages Werner gave the name of Formations; and his doctrine (or hypothesis, if this latter term be preferred, was, that the exterior of the earth consists of a series of these formations, laid over each other in a certain determinate order. Not that the whole series is anywhere complete; but that the relative place of its members is never departed from. Thus in the ascending series $\mathrm{A}, \mathrm{B}, \mathrm{C}, \mathrm{D}$, it may happen that $\mathrm{B}$ or $\mathrm{C}$, or both, may be occasionally wanting, and consequently $\mathrm{D}$ be found immediately above $\mathbf{A}$; but the succession is never violated, nor the order inverted, by the discovery of $A$ above the formations $B$, or $\mathrm{C}$, or $\mathrm{D}$, nor of $\mathrm{B}$ above those that follow it, \&c.*

A very important exception, however, to this regularity of arrangement, is found in the position of that great class of compound rocks, which includes all those of the trap family, the porphyries, syenites, and some at least of the granites of Werner. The compounds of this tribe, in general, agree, not only in possessing the characters of crystallization, and in being wholly destitute of organic remains, but in exhibiting, at their junction with the stratified substances, the

[* The substance of this and the following paragraphs, is taken from a preceding article in the Edinburgh Review, by the author of the present paper; Vol. xxix. Nov. 1817, p. 7l.] 
most obvious marks of violent derangement; and the trap rocks, in the form of large and numerous veins, are found to traverse, indiscriminately, all the other formations. It is impossible, then, to believe, that the same laws have governed the disposition, both of these compounds, and of the strata which contain organic remains, and exhibit greater uniformity of structure; and every arrangement which assigns to both a common origin, or attempts to include the trap, and other similar formations, in the general series of rocks, must be defective, and radically inconsistent. The capital mistake of Werner (to which he was led, no doubt, by an erroneous theory), was, that he attempted such a combination, and neglected those demonstrations of violence and disturbance.

In England, although the greater part of the country wants the more striking features of the primitive tracts, it fortunately happens that the series of secondary strata is nearly complete; and, when our great extent of coast is taken into the account, few countries present a field for geological observation in which the phænomena are at once so varied and so well displayed. It will soon be perceived that the inferences from Mr. Smith's examination of this country, coincide, to a great extent, with those of Werner: and this coincidence, between the results obtained by two independent observers, through channels of inquiry so different, is no small confirmation, both of the fidelity of their observations, and of the correctness of their deductions from them.

[To be continued.]

LI. Observationes quædam ad NarcissinëLs spectantes; Autore A. H. Hawor'th, Soc. Linn. Lond.-Soc. Horticult. Lond.-Soc. Cas. Nat. Curios. Mosc.-Soc. Reg. Horticult . Belgic.—necnon Bot. Reg. Ratisb., Socius : \&c. \& c.

\section{To the Editors of the Philosophical Magazine and Journal. Gentlemen,}

$\mathrm{N}$ this my thirty-second communication to your valuable and scientific Journal, a few material alterations and amendments, together with some novelties towards the improvement of my Narcissinëarum Monographia, may be acceptable to your readers; made from the living plants during the blooming season of the fine spring of 1832 , during great part of which time the fragrant Narcissinea were very ornamental, and I think finer than, up to that time, I ever beheld them. But there are nevertheless many dubious points $I$ am not even yet able completely to clear up respecting these intricate $2 \mathrm{~N}_{2}$ 